\title{
POLLEN PRODUCTION IN SELECTED SPECIES OF ANEMOPHILOUS PLANTS
}

\author{
Krystyna Piotrowska \\ Department of Botany, University of Life Sciences, Akademicka 15, 20-095 Lublin, Poland \\ e-mail: krystyna.piotrowska@up.lublin.pl
}

Received: 14.03 .2008

\section{S u m m a r y}

In the study, structural features of flowers of the following allergenic plant species were analysed: Betula verrucosa, Secale cereale, Rumex acetosella, Plantago major and Artemisia vulgaris. Pollen production was established by calculating the number of pollen grains produced by the stamen, flower and inflorescence. The dates of occurrence and pollen grains concentration in the air of Lublin were determined.

A positive correlation was found between the length of anthers and the number of pollen grains produced. The largest number of pollen grains per anther is produced by Secale cereale (22 360), whereas the smallest one by Plantago major (5 870). The other species produced intermediate numbers of pollen grains in the anther: Betula verrucosa - 11 160, Rumex acetosella -10 850, Artemisia vulgaris - 9 580. The birch pollen season in Lublin lasts about a month, and pollen of this taxon reaches the highest airborne concentrations among the studied taxa. Low values of pollen concentrations are characteristic for rye and plantain, whereas slightly higher values are recorded for sorrel pollen. Mugwort pollen reaches high concentrations which are noted at the beginning of August.

Key words: Betula verrucosa, Secale cereale, Rumex acetosella, Plantago major, Artemisia vulgaris, pollen production, atmospheric pollen season

\section{INTRODUCTION}

Every year anemophilous plants release to the atmosphere huge amounts of pollen. The abundance of pollen is related to the number of pollen grains produced by the stamen and the flower. Levels of pollen production also depend on the number of flowers and inflorescences on a plant, as well as the conditions in which it grows. For example, it is important whether a plant occurs solitary or forms clusters with other individuals (Faegri and Iversen, 1978; Molina et al. 1996). For pollen to perform its basic function, anemophilous plants must produce it in very large amounts. The volume of this production depends primarily on the length of anthers and the size of pollen grains (D y a k o w s k a, 1959; De Vries, 1971; Agnihotri and Singh, 1975; Subba Reddi and Reddi, 1986; Molina et al. 1996; Weryszko-Chmielewska and Barty ś, 2000). Weather conditions during the formation of flower buds are also of great importance. Optimal conditions at the time of formation of birch flowers are created by the temperature of $15-20^{\circ} \mathrm{C}$ together with a long day. In natural conditions, birch flowers set in June; an acceleration of this process by two months was obtained in a greenhouse after creating an appropriate temperature and illumination (S u s z k a, 1979).

The aim of the study was to characterise ecological properties of flowers and to establish pollen production of selected species of anemophilous plants as well as to determine the dates of occurrence of airborne pollen grains of several taxa.

\section{MATERIALS AND METHODS}

In the study, structural features of flowers of the following allergenic plant species were analysed: Betula verrucosa Ehrh. (syn. Betula pendula Roth.), Secale cereale L., Rumex acetosella L., Plantago major L. and Artemisia vulgaris L. Measurements were made of particular flower elements, the number of stamens in the androecium as well as the average number of flowers per inflorescence and per plant were determined in twenty herbaceous plants of each species. In the case of birch, the number of flowers per inflorescence was established based on the examination of 30 inflorescences sampled from different branches of three trees. The number of pollen grains produced per anther was determined and the obtained results were then recalculated per flower and per inflorescence, and in the case of the herbaceous plants, also per plant. Mature stamens were sampled for the investigation before anther dehiscence. Pollen grains were washed out of the thecae with $70 \%$ alcohol onto a microscope slide using a stereoscopic microscope. Six replications were made for each species. 
The size of pollen grains of the studied plants was determined based on the dimensions of their polar (P) and equatorial (E) axes. 200 pollen grains were measured for each species.

The period of occurrence of airborne pollen - the atmospheric pollen season - and pollen concentrations were established using a Lanzoni VPPS 2000 pollen trap. The study was conducted in Lublin in the years 20012007. The pollen trap was located on the roof of the building of the University of Life Sciences $\left(51^{\circ} 14^{\prime} 37^{\prime \prime} \mathrm{N}\right.$ and $22^{\circ} 32^{\prime} 25^{\prime \prime} \mathrm{E}$ ) at a height of $18 \mathrm{~m}$ above ground.

\section{RESULTS}

Silver birch (Betula verrucosa Ehrh.) is one of tree species most frequently used for landscape plantings due to its decorative values and low habitat requirements. The common occurrence of this species is however adverse to many people allergic to birch pollen which contains one of the strongest allergens. Male inflorescences of silver birch are set in the summer of the previous year. In August they are already clearly visible. The measurements show that at that time they grow up to a height of $1.5-2 \mathrm{~cm}$. Immediately before flowering, these inflorescences reach a length of about $4 \mathrm{~cm}$. During flowering, the inflorescence axis elongates up to about $7 \mathrm{~cm}(10 \mathrm{~cm}$ at a maximum). On the average, 150 three-flowered cymes are clustered in male inflorescences; they grow spirally on the inflorescence axis (Fig. 1) and form secondary catkin inflorescences. Each cyme is subtended by a scaly, sparsely haired outer bract with the dimensions of $2.0 \mathrm{~mm} \times 1.6 \mathrm{~mm}$ (Fig. 2). Particular flowers grow in the axils of the inner bracts reaching the dimensions of $1.0 \mathrm{~mm} \times 1.2 \mathrm{~mm}$ (Fig. 3). The male inflorescences investigated in the present study had an average of 450 flowers.

The male birch flower is subtended by two perianth segments ( $1.8 \mathrm{~mm} \times 0.8 \mathrm{~mm}$ ) enclosing 2 stamens (Fig. 3), with the anthers composed of two separate thecae (Fig. 4). That is why it seems that there are 4 stamens in the flower. The anthers reach the dimensions of $1.44 \mathrm{~mm} \times 0.73 \mathrm{~mm}$. Birch pollen grains are triporate and they are classified as small. Their dimensions were $21.34 \mu \mathrm{m} \times 18.17 \mu \mathrm{m}$ (Fig. 5). The calculations show that there are, on the average, 900 stamens in one inflorescence, and each of them produces 11160 pollen grains, thus the number of pollen grains per inflorescence is 10044000 (Tab. 1).

Female birch catkins grow in quite large density on short lateral shoots, below their apex. They are erect or slightly hanging. They are characterised by much smaller dimensions than male catkins, since they reach $1.52 \times 0.17 \mathrm{~cm}$. Similarly to male inflorescences, they contain three-flowered cymes (Fig. 6). A single female

Table 1

Anther length and average numbers of pollen grains of the studied plant species (the order of species is presented in accordance with anther length).

\begin{tabular}{|c|c|c|c|c|}
\hline \multirow{2}{*}{ Species } & \multirow{2}{*}{$\begin{array}{c}\text { Anther length } \\
{[\mathrm{mm}]}\end{array}$} & \multicolumn{2}{|c|}{ Number of pollen grains produced by: } \\
\cline { 3 - 5 } & & stamen & flower & inflorescence \\
\hline Secale cereale & 9.50 & 22360 & 67080 & 4024800 \\
\hline Betula verrucosa & 1.44 & 11160 & 22320 & 10044000 \\
\hline Artemisia vulgaris & 1.27 & 9850 & 49250 & 640250 \\
\hline Rumex acetosella & 1.13 & 10850 & 65100 & 4557000 \\
\hline Plantago major & 0.91 & 5870 & 23480 & 6339600 \\
\hline
\end{tabular}



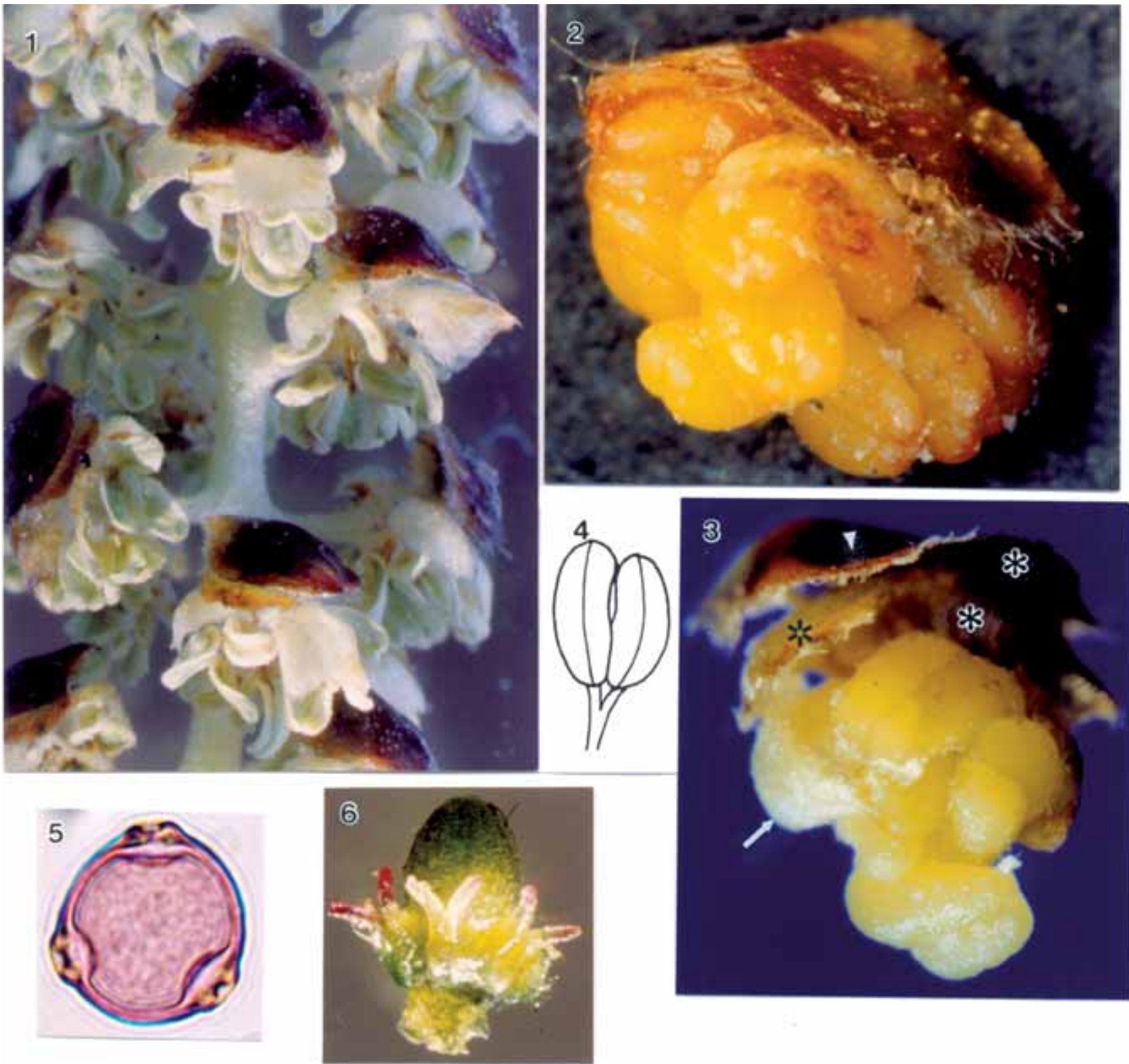

Figs 1-6. Betula verrucosa

Fig. 1. Loosely arranged cymes with stamens empty of pollen, $x 12$.

Fig. 2. Cymes with three male flowers, $x 30$.

Fig. 3. Single male flower. Parianth segment (arrow), outer bract (arrow head) and 3 inner bracts (stars) are visible, x 25.

Fig. 4. Schematic diagram of the stamen structure, $x 16$.

Fig. 5. Pollen grain - LM x 1300.

Fig. 6. Cyme with three female flowers, x 28. 
flower is devoid of the perianth; it is composed of one pistil growing in the axil of the inner bract. The bracts are fused forming 3-lobed scale protecting the winged nutlet.

Common rye (Secale cereale L.) belongs to cereal plants often grown in Poland. Pollen grains of this plant exhibit a high degree of allergenic activity.

The spikes of Secale cereale cv. Dańkowskie Złote were 9.4 long, on the average. Each of them had an average of 60 flowers. The anthers reach large dimensions of $9.50 \mathrm{~mm} \times 0.97 \mathrm{~mm}$ (Fig. 7) and they are borne on a filament which initially is relatively short, as it reaches $1.6 \mathrm{~mm}$, but before pollen shedding, during lemmae and paleae opening, it rapidly increases its length up to about $9.2 \mathrm{~mm}$.

Pollen grains are shed in batches through elongated slits, starting from the apical part of the theca. Pollination starts before the stamens come out completely from the lemmae and paleae. Particular stamens of the flower mature successively. During the gradual elongation of the successive stamens, each of them touches the adjacent stamen, provoking pollen shedding. The process of elongation and coming out of three stamens from between lemma and palea takes about 2 minutes. Within about 5 minutes, the thecae empty half of their content, and after 1.5 up to 2 hours they are empty. The apical portion of the thecae forms characteristic bowl-shaped fragments in which pollen is caught in windless weather (Fig. 8).

Spikelets in the middle part of the spike flower first. The further opening of the anthers takes place in both directions. In sunny weather, pollen shedding from one rye spike lasted 4 days, whereas the rye canopy bloomed for 14 days.

Rye pollen grains are oval, heteropolar, monoporate (Fig. 9). In the examined material, they reached the dimensions of $48.55 \mu \mathrm{m} \times 34.92 \mu \mathrm{m}$. It was calculated that one stamen of Secale cereale produced an average of 22360 pollen grains, whereas the spike produced 4024800 of them (Tab. 1).

The pistil of Secale has two stigmas with a length of $3.5 \mathrm{~mm}$. The feathery stigmas developed an increased catching surface for sporomorphs borne by the wind. Each filiform element of the stigma has outgrowths facilitating pollen capture (Figs 11, 11). Two membranous lodicules, haired at the apex, adhere to the ovary $(1.2 \mathrm{x}$ $0.9 \mathrm{~mm}$ ) (Fig. 10).

In Poland several sorrel species are found whose pollen causes allergies. One of them is Rumex acetosella L., field sorrel, which is a unisexual, dioecious plant (Fig. 12) growing up to a height of $25-55 \mathrm{~cm}$. Severalflowered clusters grow on the stem alternately in three sections. The stalk base is subtended by a small bract and membranous, fimbriate-laciniate ochrea (Fig. 12).

Male flowers usually grow in clusters of $5-6$, at an average distance of $4.6 \mathrm{~mm}$ from each other. The un- differentiated green-red perianth forms tripartite whorls: the outer whorl with smaller segments $(1.3 \mathrm{~mm}$ x 0.6 $\mathrm{mm}$ ), fused at their bases, and a more impressive inner whorl $(1.6 \mathrm{~mm} \times 1.2 \mathrm{~mm})$. The flower pedicle grows up to $2.7 \mathrm{~mm}$. In the flower, six stamens grow whose yellow-coloured anthers reach the dimensions of $1.13 \mathrm{~mm}$ $\mathrm{x} 0.64 \mathrm{~mm}$. The thecae are not joined from the top down to almost half of their length (Fig. 14). During anthesis, the flowers are directed downwards and the perianth segments straighten up, being arranged in a horizontal plane and forming a protective "roof" over the freely hanging stamens on the filaments about $1 \mathrm{~mm}$ long. After pollen release, the anthers drop off (Fig. 13).

Tricolporate pollen grains of field sorrel can be classified as small, since their dimensions reached 22.1 x $20.0 \mu \mathrm{m}$. Inside the cells of pollen grains, large reserve starch grains were visible (Fig. 15).

The investigated male plants formed few branches $(4-7)$ on which 70 flowers develop, on the average, irrespective of the plant height. One field sorrel plant, depending on the number of branches, produced 280 - 490 flowers and $18233040-31907820$ pollen grains (Tab. 1).

In the female plants, the inflorescences usually bore 7 flowers at an average distance of $3 \mathrm{~mm}$ between the nodes. The female flowers are triangular shaped (Fig. 16), with this shape being formed by the three-edged ovary of the pistil. Similarly to the male flowers, the double, three-segmented perianth is composed of smaller greenish-coloured outer segments and larger green- or red-coloured inner segments. The dimensions of flowers are $1.1 \mathrm{~mm} \times 0.9 \mathrm{~mm}$. Three stigmas of the pistil grow on very short styles fused to the ovary edges (Fig. 17). Single stigmas resemble a small star with over a dozen arms and a diameter of $1 \mathrm{~mm}$.

Greater plantain, i.e. common plantain (Plantago major L.), is one of the most commonly found ruderal plants in Poland. Its pollen causes allergies in sensitive people.

Leafless plantain shoots ended with spikelike inflorescences reach different heights. They are short in trodden places and grow up to $60 \mathrm{~cm}$ under favourable conditions. Generally, the inflorescence stem is slightly longer than the spike.

Bisexual plantain flowers grow in the axils of the bracts similar to calyx sepals (Fig. 18). The membranous-edged sepals $(1.6 \times 1.1 \mathrm{~mm})$ with a green band of assimilation tissue in the middle are free and they grow in two whorls in twos (Fig. 18). The flower corolla, with fused petals, is greenish and transparent, reaching 22 $\mathrm{mm}$ in length. It produces four small bent lobes. The filaments of 4 stamens are fused to the corolla tube in interopositus way. Their anthers are claret-coloured (major variety) (Fig. 19), sometimes yellow-coloured (sulphurea variety) (Fig. 20). Before the stamens come out, the anthers tightly hold the style and the long fila- 

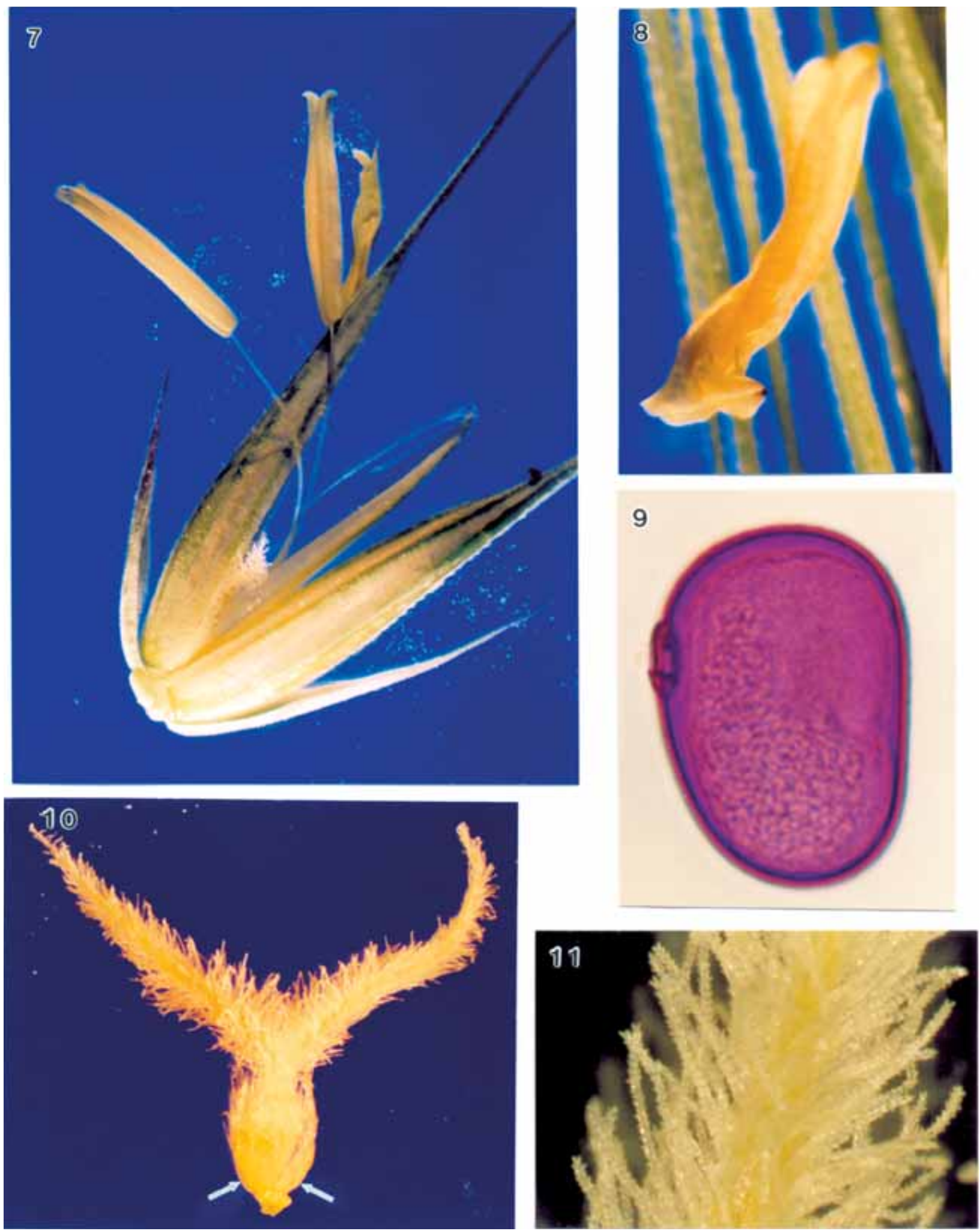

Figs 7-11. Secale cereale

Fig. 7. Two-flowered spikelet, $\mathrm{x} 4,5$.

Fig. 8. Stamen with bowl-shaped fragments in the apical portion of the thecae, $x 9$.

Fig. 9. Pollen grain with annulus around porus, $x 1320$.

Fig. 10. Pistil with two stigmas and lodicules (arrow), $x 17$.

Fig. 11. Filiform elements of the stigma, $x 70$. 

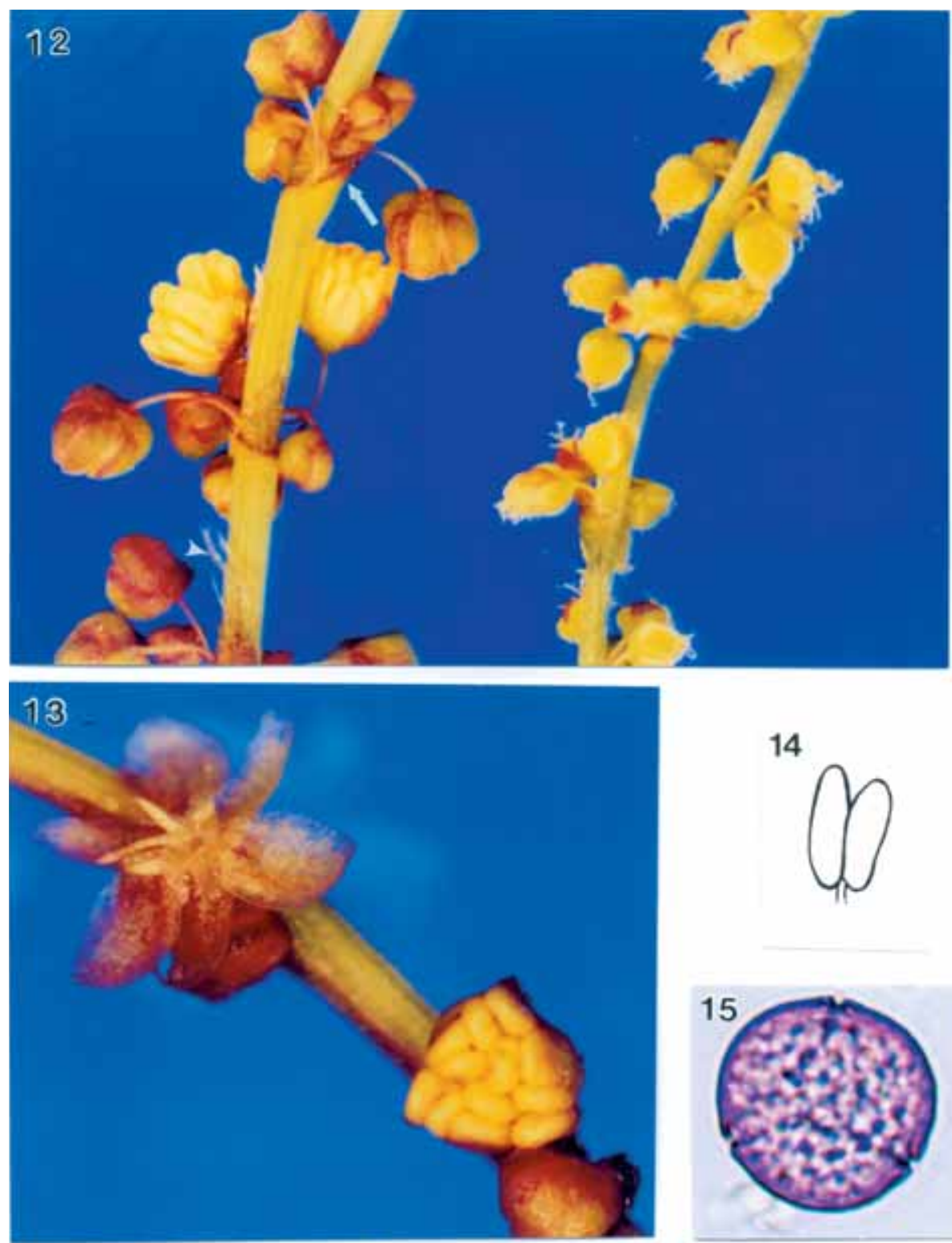

14
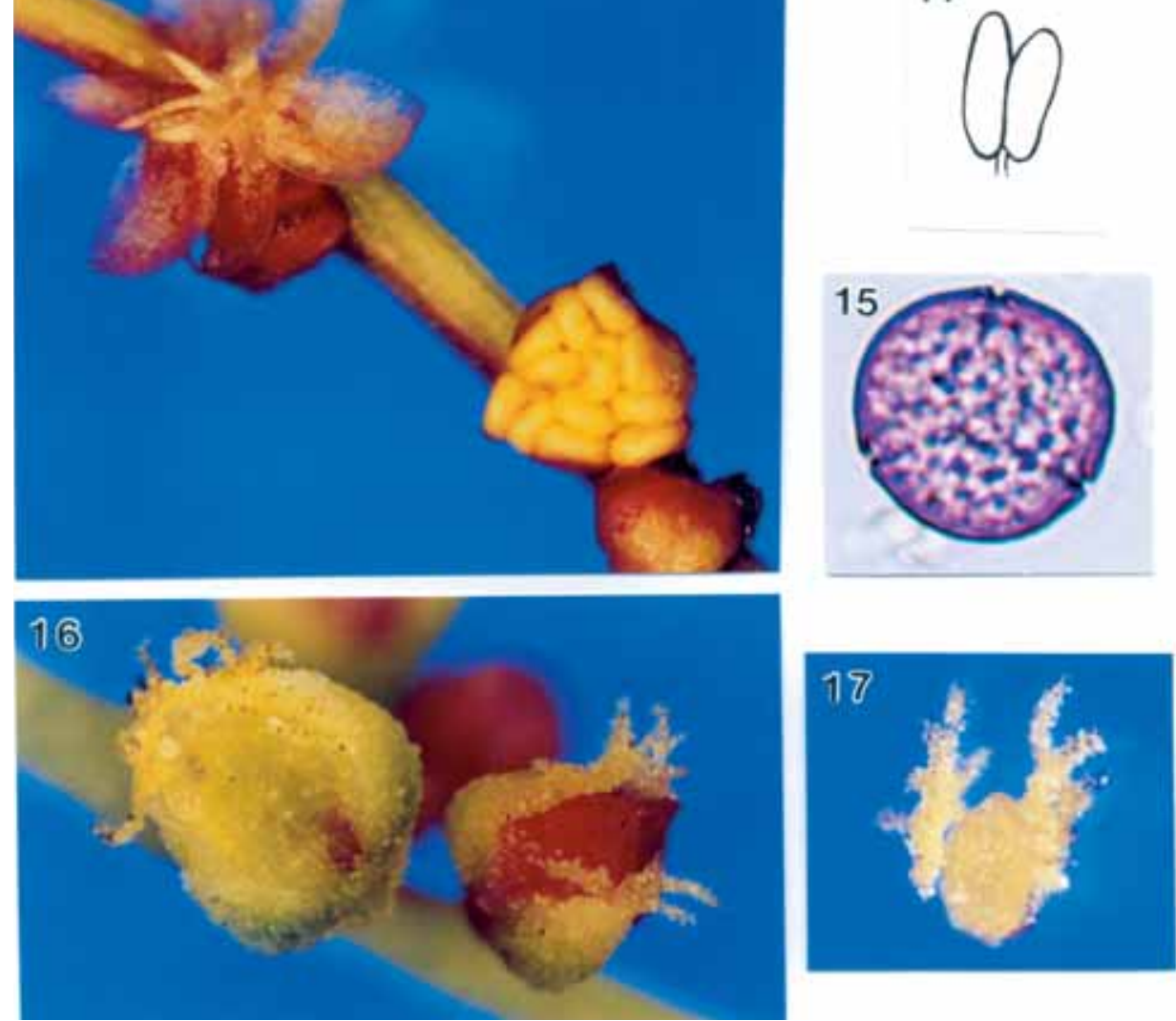

Figs 12-17. Rumex acetosella

Fig. 12. Fragments of male and female plants, bract (arrow) and ochrea (arrow head) visible on the stem, $x 10$.

Fig. 13. Male flowers at different development stages. On the left, the flower after anthesis without anthers, perianth segments and filaments are visible, $\mathrm{x} 12$.

Fig. 14. Schematic diagram of the stamen structure, $\mathrm{x} 16$.

Fig. 15. Pollen grain - LM x 1100.

Fig. 16. Female flowers with green and red inner parianth segments, $x 30$.

Fig. 17. Pistil with star-shaped stigmas (two out of three are visible), $\mathrm{x} 25$. 

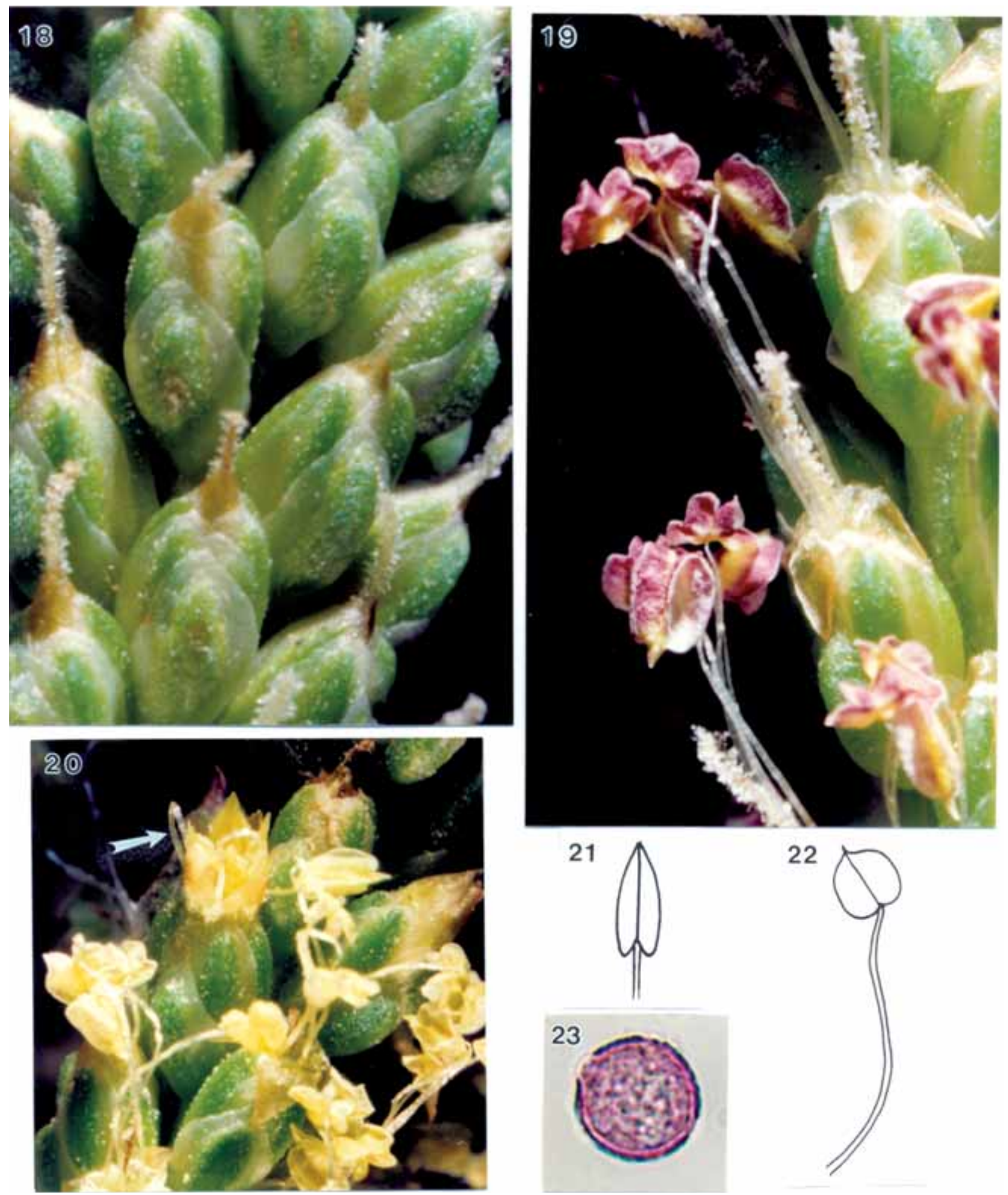

Figs 18-23. Plantago major

Fig. 18. Flowers in the pistil stage, $\mathrm{x} 23$.

Fig. 19. Flowers in the stamen stage, $\mathrm{x} 20$.

Fig. 20. Flowers at different development stages. In the upper part, a flower with stamens coming out, the filament folded in two (arrow), $x 18$.

Fig. 21. Schematic diagram of the stamen structure before pollination, $\mathrm{x} 16$.

Fig. 22. Schematic diagram of the stamen structure during pollination, $\mathrm{x} 16$.

Fig. 23. Pollen grain - LM x 1020. 

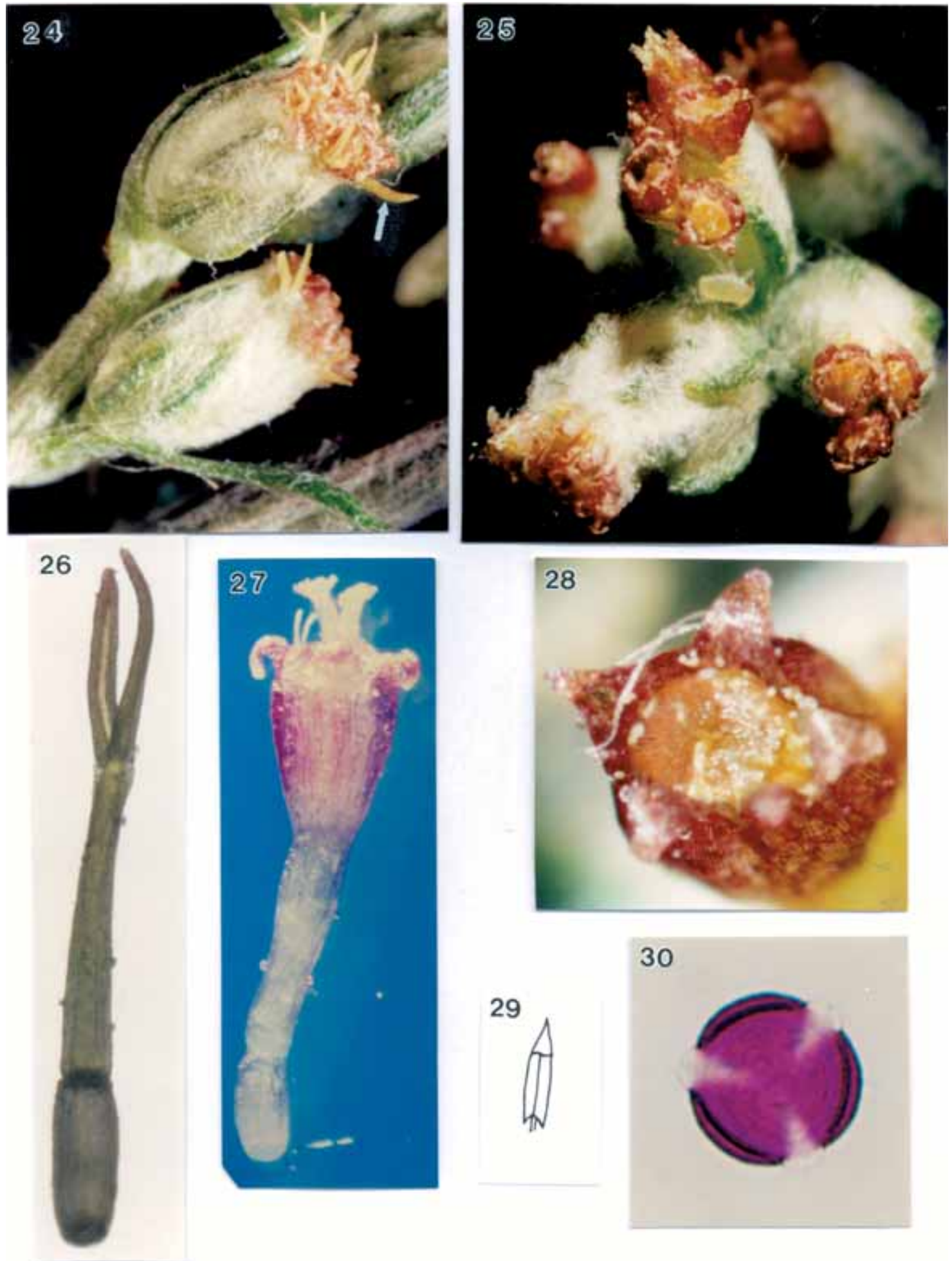

Figs 24-30. Artemisia vulgaris

Fig. 24. Capitula at the flowering stage. On the circumference, visible are ray flowers with long yellow-coloured stigmas (arrow), inside disc flowers, $\mathrm{x} 17$.

Fig. 25. Flowers during anthesis, $x 17$.

Fig. 26. Ray flower, $x 38$.

Fig. 27. Disc flower, $x 33$.

Fig. 28. Corolla tube tightly closed by outgrowths of anthers, $\mathrm{x} 50$.

Fig. 29. Schematic diagram of the stamen structure, $\mathrm{x} 16$.

Fig. 30. Pollen grain - LM x 1320. 
ment (3.5 mm) is folded in two (Fig. 20). At this stage, the anthers are longer and narrower $-1.25 \mathrm{~mm} \times 0.55$ $\mathrm{mm}$, but right before pollen shedding their dimensions change to $0.91 \mathrm{~mm} \times 0.74 \mathrm{~mm}$ (Figs 21, 22). The pistil has a long filiform style ended with an undivided, elongated stigma (Figs 18, 19).

Plantain pollen grains are polyporate, spherical (Fig. 23). Their diameter was $21.15 \mu \mathrm{m}$, on the average. In the case of my study, the spikes of the plants reached a length of from 2 up to $35 \mathrm{~cm}$. It was determined that an average of 18 flowers developed per $1 \mathrm{~cm}$ of inflorescence length. It was calculated that 5870 pollen grains were produced in one anther, thus a spike with an average length of $15 \mathrm{~cm}$ can produce 6339600 pollen grains (Tab. 1).

Plantain flowers are protogynous. In accordance with the sequence of development of racemose inflorescences, the blooming process first takes place in the lowest located flowers. One spike flowers 6 days, on the average. Particular inflorescences grow and bloom successively. One plant can produce a maximum of about 20 spikes.

Mugwort (Artemisia vulgaris L.) is a permanent component of vegetation accompanying man. It occurs in ruderal sites, on roadsides, in wasteland. It is found in all the housing estates of Lublin, and on the outskirts of the city this weed infests meadows and non-agricultural land, often forming dense canopies. Mugwort pollen is one of the most frequent causes of pollinosis in Poland

Under favourable conditions, mugwort produces strongly branched plants, growing up to $2 \mathrm{~m}$. Depending on the degree of branching and plant height, it produces a different number of capitula. By way of example, a mugwort plant $140 \mathrm{~cm}$ high and with 23 primary branches produced 4987 inflorescences. It was calculated that the investigated plants produced an average of 8 flower heads per $1 \mathrm{~cm}$ of a branch with flowers. A plant with 4987 flower heads can produce 3192926750 pollen grains (Tab. 1).

Closed capitula are egg shaped; shortly before flowering, their size is $2.6 \mathrm{~mm} \times 1.8 \mathrm{~mm}$, whereas during flowering they reach the dimensions of $4.0 \mathrm{~mm} \times 2.5$ $\mathrm{mm}$. The inflorescences are covered with membranousedged bracts of the involucre arranged in three 5-leaved whorls. The outer side of the bracts is strongly haired (Fig. 24), the inner side is smooth. In the present study, it was calculated that one flower head was composed, on the average, of 9 female ray flowers situated on the circumference (Fig. 24, 26) and inside 13 bisexual disc flowers (Figs 25, 27) borne on the convex inflorescence receptacle.

The disc flowers develop asynchronously in the flower head and their blooming also starts not simultaneously. The flowers measured during flowering were $2.5-3 \mathrm{~mm}$ long. The corolla was initially transparent, greenish-yellow and it tightly shrouded the stamens and pistil. During flowering, it took on the claret colour.

In their apical portion, the linear thecae, with the dimensions of $1.27 \mathrm{~mm} \times 0.28 \mathrm{~mm}$, have membranous, pointed outgrowths which probably perform a protective role for the pistil and the flower inside, since, being bent inwardly, they tightly close the entry to the corolla tube (Figs 28, 29). The anthers become fused with one another right before anthesis. It points out to the fact that particular stamens can be isolated without any problem from the flowers at the bud stage. Following the petal fall stage, the anthers remain joined. The bisexual flowers have a pistil with a sigma $0.4 \mathrm{~mm}$ long, ended with two pollen presenters with glistening hairs. They function like a piston, pushing out pollen from the anthers and the stamen tube and raising it above the corolla level (Fig. 27).

The ligulate corolla of the female flowers is transparent, with an elongated tube tightly adhering to the style (Fig. 21). The ligule reaches a length of $0.2 \mathrm{~mm}$; two lobes are sometimes found in the top part of the corolla. The young perianth is greenish-yellowish-coloured; at a later stage of development, its upper part as well as the stigmas and apical fragments of the style become claret-coloured. The stigmas of the pistil reach large dimensions. Their length can be as much as $0.7 \mathrm{~mm}$, whereas the whole flower reaches a length of $3 \mathrm{~mm}$.

The average size of tricolporate pollen grains was $21.62 \times 19.23 \mu \mathrm{m}$ (Fig. 30).

The studied species produced a different number of pollen grains per stamen. A clear correlation was found between anther length and number of pollen grains per stamen. The results relating to pollen production in the studied plant species are presented in Table 1.

Based on the results of pollen monitoring conducted under the seven-year-long study in Lublin, the average start and end dates of pollen seasons of the studied plant genera were established; they also included species other than those mentioned in the table due to the fact that it was impossible to distinguish their pollen. In Figure 31, the average duration of the pollen season is marked in dark colour, and in bright colour - the extreme start and end dates of the season over the seven-yearlong period of study. Birch pollen grains are present in the air of Lublin, on the average, from the middle of April until the middle of May. The birch pollen season was recorded earliest from 3 April in 2002. Birch pollen reaches very high concentrations in the air. The highest average concentration from the seven-year-long study is 2364 pollen grains per day (Fig. 32). The rye pollen season lasts relatively short, on the average, from 23 May to 17 June. It started earliest on 13 May, also in 2002 (Fig. 31). The maximum pollen concentration of this taxon appears at the end of May or at the beginning of June. These are relatively low values (Fig. 33). 


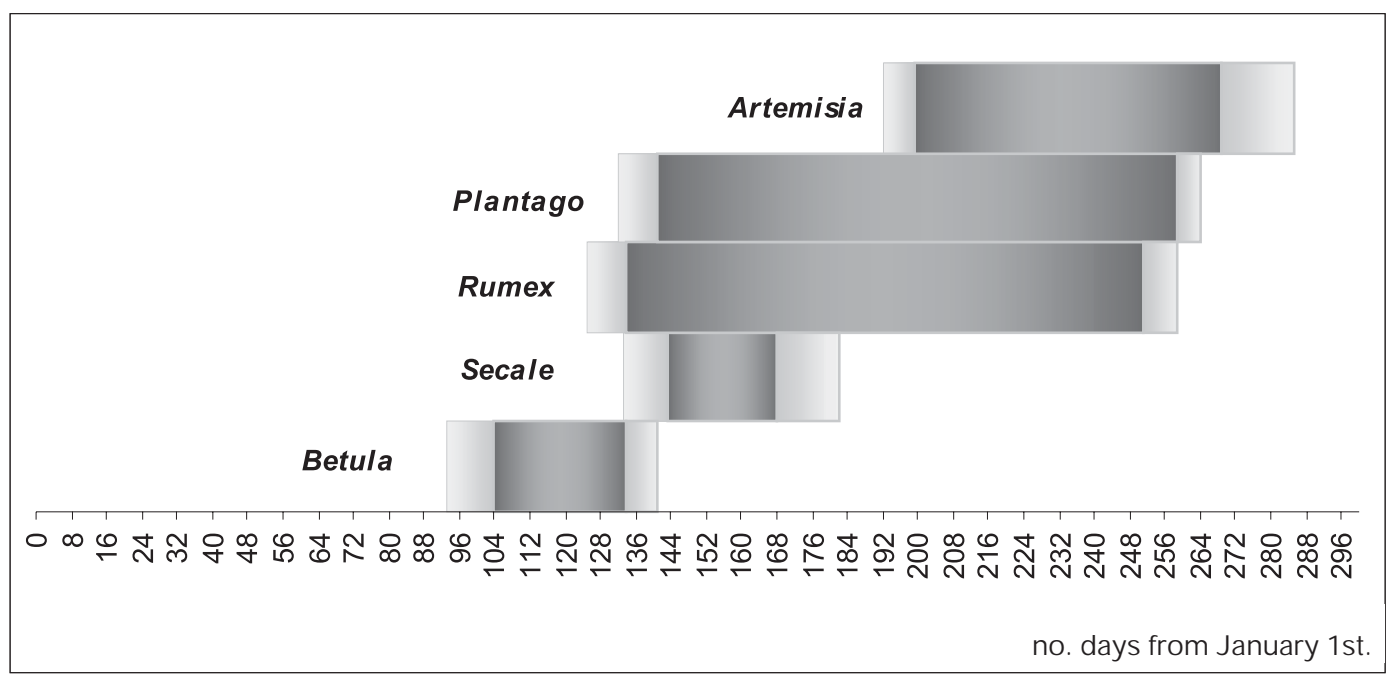

Fig. 31. The mean and extreme terms of the pollen seasons beginning and end of the selected taxa plants (averages from 2001-2007).

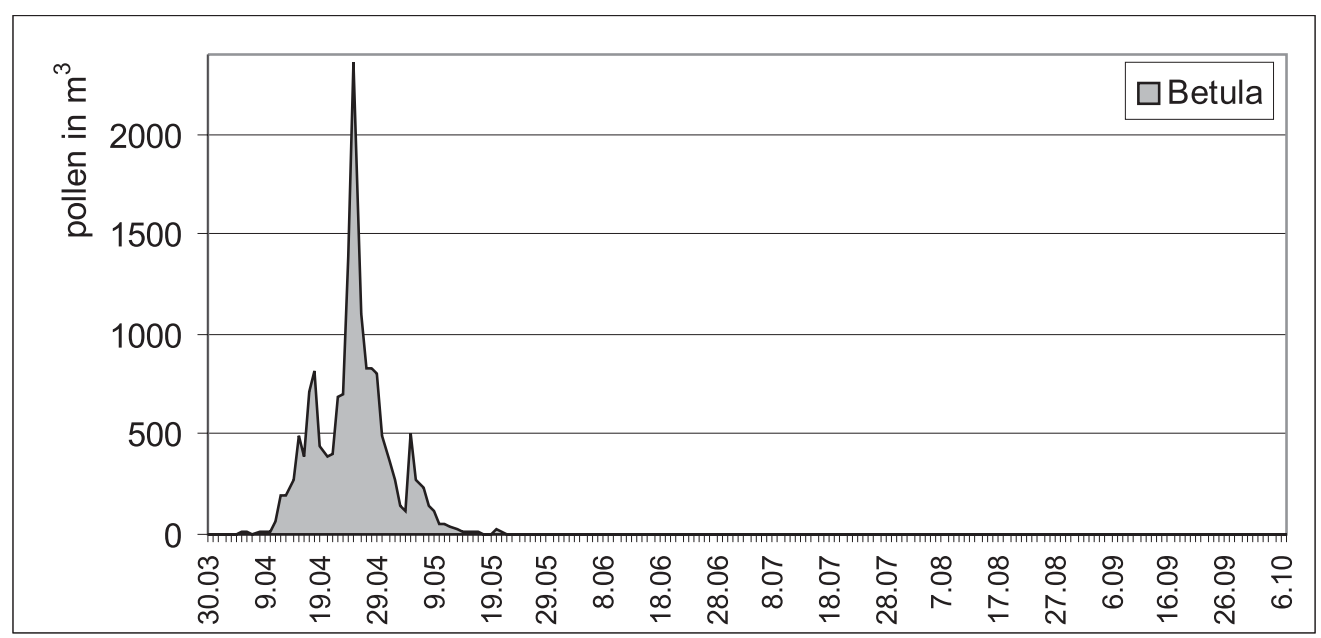

Fig. 32. Betula pollen in the air of Lublin (averages from 2001-2007).

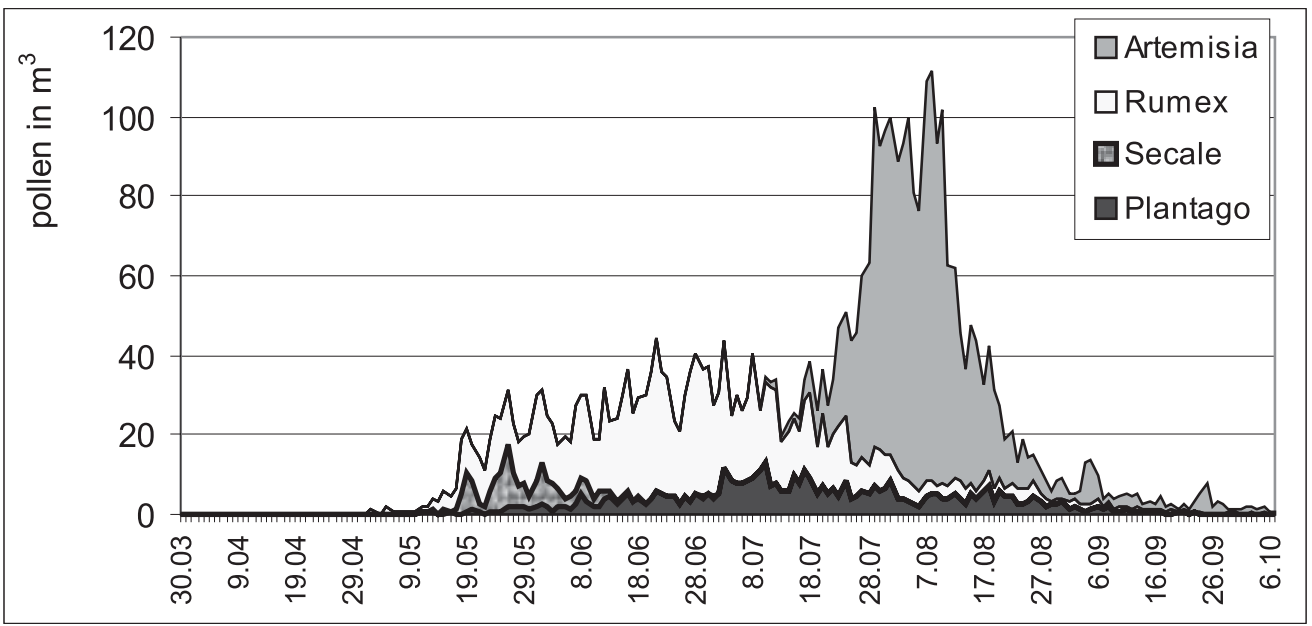

Fig. 33. Comparison of Artemisia, Rumex, Secale and Plantago pollen season (averages from 2001-2007). 
The dates of Rumex and Plantago pollen seasons coincide to a large extent, but sorrel pollen grains are mostly recorded a week earlier than plantain pollen. The average duration of the sorrel and plantain pollen seasons is similar - 118 and 119 days, respectively. The average sorrel pollen season lasted from 14 May to 8 September, whereas for plantain from 21 May to 16 September (Fig. 31). Plantago pollen reaches low airborne concentrations (Fig. 33). In July (on the average, 18 July), the mugwort season starts and it lasts until 26 September. The maximum airborne pollen concentration for this taxon in the air of Lublin occurs at the beginning of August (Fig. 33).

\section{DISCUSSION}

The number of airborne sporomorphs is of special significance in aerobiology. The plant species causing allergic reactions, and the same time frequently occurring in the conditions of Lublin, were selected for our observations. Adaptations to anemophily are associated with a particular structure of flowers. Among the studied plants, the Longistaminae type inflorescence (Secale, Rumex, Plantago) was predominant. Many authors note the abundance of pollen produced by anemophilous plants (Subba Redi and Reddi, 1986; Molina et al. 1996). The number of pollen grains in one anther of the studied plants was within the range of $5870-22$ 360 . The largest amount of grains per anther was found in Secale cereale, whereas the least amount was in Plantago major, which is closely related to anther length. This correlation was confirmed by many authors (Dyakowska, 1959; De Vries, 1971; Agnihotri and Singh, 1975; Subba Reddi and Reddi, 1986; Molina et al. 1996). Also WeryszkoChmielewska and Bartyś (2000) found that the number of pollen grains was positively correlated with anther length in entomophilous meadow plants. The size of pollen grains is also of essential importance. Molina et al. (1996) demonstrated that Acer negundo produces, in an anther which is twice longer than the anthers of common olive and with medium-sized pollen grains $(27,2 \times 30,5 \mu \mathrm{m})$, a similar number of pollen grains as Olea europaea producing small pollen grains $(22 \mu \mathrm{m})$. But Juglans regia produces 18 times less pollen grains than common olive in the anther of small length, as it is slightly shorter than the anther of common olive, and with medium-sized sporomorphs $(45 \mu \mathrm{m})$.

In the present study, consistent results were obtained with data given by other authors with respect to the number of pollen grains contained in the rye inflorescence and the birch flower. According to literature data, a single flower of Betula verrucosa produces 20 145 pollen grains, whereas Secale cereale -57310 . The number of pollen grains produced by the inflorescence is estimated at 5450000 for Betula verrucosa, and for
Secale cereale - 4250000 (P o h 1, 1937 following Erdtman, 1954; Dyakowska, 1959; Maurizio and Grafl, 1969; Szafer and Wojtusiakowa, 1969). A similar number of pollen grains per rye inflorescence, amounting to 4200000 , was obtained by De Vries (1971). No literature data has been found relating to pollen production by Rumex acetosella, Plantago major and Artemisia vulgaris. De Vries (1971) as well as Agnihotri and Singh (1975) stress the variation in numbers of pollen grains produced between species of the same genus, and even between the varieties. It has been shown that different wheat varieties may produce in one anther from 856 up to 3867 pollen grains (D e Vries, 1971). Significant differences in the number of pollen grains produced by different species of the same genus were also found by Subba Reddi and Reddi (1986).

The period of birch pollen shedding is relatively short; there is generally only one high peak on the curve presenting the pollen season pattern. It is attributable to the fact that $70-80 \%$ of pollen is released from the anthers of birch within 2-3 days ( $\mathrm{S} \mathrm{u} \mathrm{s} \mathrm{zk} \mathrm{a,} \mathrm{1979).} \mathrm{The}$ intensity of the birch pollen season differs significantly between particular years and depends, inter alia, on the number of inflorescences produced in the previous year (L a u k kan en et al. 2003). The occurrence of airborne rye pollen is characterised by great regularity. Maximum concentrations in Lublin in the years 1994-1997, likewise in the years 2001-2007, were found at the end of May or at the beginning of June (P i otrow ska, 1999). In Lublin plantain pollen was noted from 21 May, on the average. A comparison of the pollen seasons in Lublin, Poznań and Rzeszów shows that Plantago pollen appeared earliest in Rzeszów (at the beginning of May) and latest in Poznan (at the end of May), whereas the dates of occurrence of Rumex pollen in the three cities were similar (P i o trow ska, 2007). In Lublin the mugwort pollen season starts about the middle of July. When comparing the dates of occurrence of pollen of the abovementioned taxon in the air of 8 cities, it was found that it appears in the western part of Poland earlier than in the eastern part (Weryszko-Chmielewska et al. 2006). In the recent years, an ever increasing number of people allergic to mugwort pollen has been recorded. Rapiejko and Weryszko-Chmielewska (1999) note that it can be associated with an increased share of pollen of these plants in aeroplankton.

\section{REFERENCES}

Agnihotri M. S., Singh B. P., 1975. Pollen production and allergenic significance of some grasses around Lucknow. Jour. Palynol. 11: 151-154.

De Vries A.Ph., 1971. Flowering biology of wheat, particularly in view of hybrid seed production - a review. Euphytica, 20: 152-169. 
Dyakowska J., 1959. Podręcznik palynologii. Wydawnictwa Geologiczne, Warszawa.

Erdtman G., 1954. An introduction to pollen analysis. Waltham, Mass., USA.

Faegri K., Iversen J., 1978. Podręcznik analizy pyłkowej. Wydawnictwa Geologiczne, Warszawa.

Laukkanen L. I., Lehtimäki S., Hokkanen T., Ranta H., Bondestam K., Rantio- Lehtimäki A., 2003. Number of male catkins of silver birch (Betula pendula) - a tool to predict birch pollen season. Third European Symposium on Aerobiology, NPRU, Worcester, UK, Abstracts: 146.

Maurizio A., Grafl I., 1969. Das Trachtpflanzenbuch. Ehrenwirth Verlag, München.

Molina R. T., Rodrigez A.M., Palacios I. S., López F. G., 1996. Pollen production in anemophilous trees. Grana, 35: 38-46.

Piotrowska K., 1999. Biologia kwitnienia i opad pyłkowy żyta (Secale cereale L.). / Biology of flowering and pollen fall of rye (Selale cereale L.). Bibl. Fragm. Agron. 6: 203208.

Piotrowska K., 2007. Kalendarze pyłkowe. / Pollen calendars. In: E. Weryszko-Chmielewska (Red.), Aerobiologia: 6367, Wydawnictwo Akademii Rolniczej w Lublinie.

Rapiejko P., Weryszko-Chmielewska E., 1999. Pyłek bylicy. / Mugwort pollen. Alergia Astma Immunologia, 4 (3), 139-142.

Subba Reddi C., Reddi S., 1986. Pollen production in some anemophilous angiosperms. Grana, 25: 55-61.

Suszka B ., 1979. Rozmnażanie generatywne. In: Białobok S. (Red.). Brzozy Betula L. Nasze drzewa leśne, 7. PWN, Warszawa-Poznań: 149-198.

Szafer W., Wojtusiakowa H., 1969. Kwiaty i zwierzęta. PWN, Warszawa.

Weryszko-Chmielewska E., Bartyś E., 2000. Correlation between stamen head traits and pollination abundance for 10 meadow species. Pszcz. Zesz. Nauk., XLIV, 2: $267-$ 275.

Weryszko-Chmielewska E., Piotrowska K., Chłopek K., Kasprzyk I., Malkiewicz M., Myszkowska D., Puc M., Stach A., MajkowskaWojciechowska B., 2006. Analiza sezonów pyłkowych bylicy (Artemisia L.) w wybranych miastach Polski w latach 2001-2005. / The analysis of mugwort (Artemisia L.) pollen seasons in selected cities in Poland, 2001-2005. In: E. Weryszko-Chmielewska (Red.) Pyłek roślin w aeroplanktonie różnych regionów Polski. Praca zbiorowa. Katedra i Zakład Farmakognozji z Pracownią Roślin Leczniczych Wydziału Farmaceutycznego Akademii Medycznej im. Prof. Feliksa Skubiszewskiego, Lublin, 2006: 133-141.

\section{Produkcja pyłku wybranych gatunków roślin wiatropylnych}

Streszczenie

W pracy analizowano cechy budowy kwiatów następujących gatunków roślin alergogennych: Betula verrucosa, Secale cereale, Rumex acetosella, Plantago major oraz Artemisia vulgaris. Określono obfitość pylenia obliczając liczbę ziarn pyłku wytwarzaną przez pręcik, kwiat i kwiatostan. Ustalono terminy występowania oraz stężenie ziarn pyłku w powietrzu Lublina.

Stwierdzono dodatnią zależność między długością pylników a liczbą wytwarzanych ziarn pyłku. Najwięcej ziarn pyłku w główce pręcikowej produkuje Secale cereale (22 360), zaś najmniej Plantago major (5 870). Pozostałe gatunki tworzyły w pręciku pośrednie ilości ziarn pyłku: Betula verrucosa - 11 160, Rumex acetosella - 10 850, Artemisia vulgaris - 9580. Sezon pyłkowy brzozy w Lublinie trwa około miesiąca, a pyłek wymienionego taksonu osiąga najwyższe koncentracje w powietrzu spośród badanych taksonów. Niskie wartości stężenia pyłku są charakterystyczne dla żyta i babki, nieco wyższe rejestrowane są dla pyłku szczawiu. Pyłek bylicy osiaga wysokie stężenia, które notowane są na początku sierpnia. 